\title{
Observations on the Nesting of the Northern Hawk Owl, Surnia ulula, near Timmins and Iroquois Falls, Northeastern Ontario, in 2001
}

\author{
Michael PATRIKEEV \\ 3 Helen Street, Dundas, Ontario L9H 1N2 Canada; e-mail: mpatrikeev@ hotmail.com
}

Patrikeev, Michael. 2006. Observations on the nesting of the Northern Hawk Owl, Surnia ulula, near Timmins and Iroquois Falls, northeastern Ontario, in 2001. Canadian Field-Naturalist 120(4): 433-437.

Three breeding pairs of Northern Hawk Owls were observed in northeastern Ontario in the vicinity of Timmins and Iroquois Falls in 2001, and two nests and a brood were recorded. The young from one nest fledged prematurely (likely due to a storm) and the another nest probably failed. Four other territorial pairs were observed. Notes on nest sites, feeding and nest attendance were taken.

Key Words: Northern Hawk Owl, Surnia ulula, nesting, northeastern Ontario, clearcuts.

The distribution and biology of the Northern Hawk Owl (Surnia ulula) have not been well documented in North America with fewer than 20 papers published on this species by the mid-1990s (Duncan and Duncan 1998). In Ontario, the Northern Hawk Owl breeds in the boreal forest zone south to latitude $48^{\circ}$, with occasional records south to Parry Sound, Algonquin Provincial Park, and Ottawa (Peck and James 1983; Weir 1987). During the first Ontario Breeding Bird Atlas (OBBA), 1981-1985, the Northern Hawk Owl was found in $0.8 \%$ of surveyed $10 \times 10 \mathrm{~km}$ squares, and during the second OBBA (2001-2004) in 4.2\% of squares (OBBA, unpublished data, courtesy of A. Heagy, Bird Studies Canada). This increase in records likely resulted from better access in the boreal forest owing to the extensive network of forest access roads built in the 1990s and early 2000s, more effort directed to northern areas, and an influx of Northern Hawk Owls in northwestern (Escott 2002) and northeastern Ontario (personal observation). Only 25 nests were reported to the Ontario Nest Record Scheme by 2004, with 21 nests from northwestern Ontario (Escott 2002; G. Peck, personal communication).

In May 2001, two nests and three additional Northern Hawk Owl territories were recorded in the drainages of the North Driftwood and Mattagami rivers in Crawford Township north of Timmins, Ontario $\left(48^{\circ} 49^{\prime} 48^{\prime \prime} \mathrm{N}, 081^{\circ} 27^{\prime} 14^{\prime \prime} \mathrm{W}\right)$. In June, a pair with a brood and another territory were found in the drainage of Shallow River in Wilkie Township, the City of Iroquois Falls (48³2'15"N, 080²7'59"W). All sites were in Cochrane District (Figure 1).

The nests found in Crawford Township (about $1.3 \mathrm{~km}$ apart) were in small stands of medium age mixed forest with low density of living trees and many tall hardwood snags, and surrounded by clearcuts. The stands consisted mostly of Black Spruce (Picea mariana) and Balsam Fir (Abies balsamea), with fewer poplars (Populus), American Larch (Larix laricina), Jack Pine (Pinus banksiana), and Paper Birch (Betula papyri- fera). A large number of snags likely indicated past herbicide treatment of deciduous trees to allow for more rapid regeneration of coniferous species. In Wilkie Township, a pair with brood occurred in a small stand of poplars defoliated by Forest Tent Caterpillars (Malacosoma disstria) and also adjacent to sizable clearcuts. Other territorial Hawk Owls hunted in wetlands (treed fen), burned areas and overgrown clearings. The nests found in 2001 were in cavities at the top of poplar snags, at 7 and $8.5 \mathrm{~m}$ above the ground (Number 1 and 2, respectively). Nest Number 1 was in a shallow cavity open from the above, and Number 2 in a cavity open on one side (Figures 2 and 3). Nest Number 1 was near the stand edge, close to a clearcut, and Number 2 was ca. $10 \mathrm{~m}$ away from a moderately used road. The nesting site in Wilkie Township was about $20 \mathrm{~m}$ from a forest access road.

Nest sites were visited between 19 May and 25 June, and nest Number 1 was observed from an elevated blind on 30 May, 11 and 12 June between 10:45 and 20:30 hours (for a total of 14.5 hours), with $10 \times$ binoculars, and a photographic camera fitted with $500 \mathrm{~mm}$ lens. It was assumed that the larger owl that spent most of the time on the nest, and cared for the young was female, and the smaller owl that brought food and made territorial calls was male [according to Duncan and Duncan (1998) incubation and brooding of the young in this species is by the female only].

In nest Number 1 incubation lasted to at least 30 May (incubation was presumed because the female remained seated on the nest, changing her position infrequently and was not seen feeding when food was delivered). At least two young in gray down (presumed to be ca. 7 days old) were seen raising heads in that nest on 11-12 June, but the nest was empty when examined on 25 June. High winds with gusts reaching $89 \mathrm{~km} / \mathrm{hour}$ resulting from the aftermath of Tropical Storm Allison reached the area on 19 June (Environment Canada website: http://www.climate.weatheroffice.ec. gc.ca), and the young might have fledged prematurely because of 


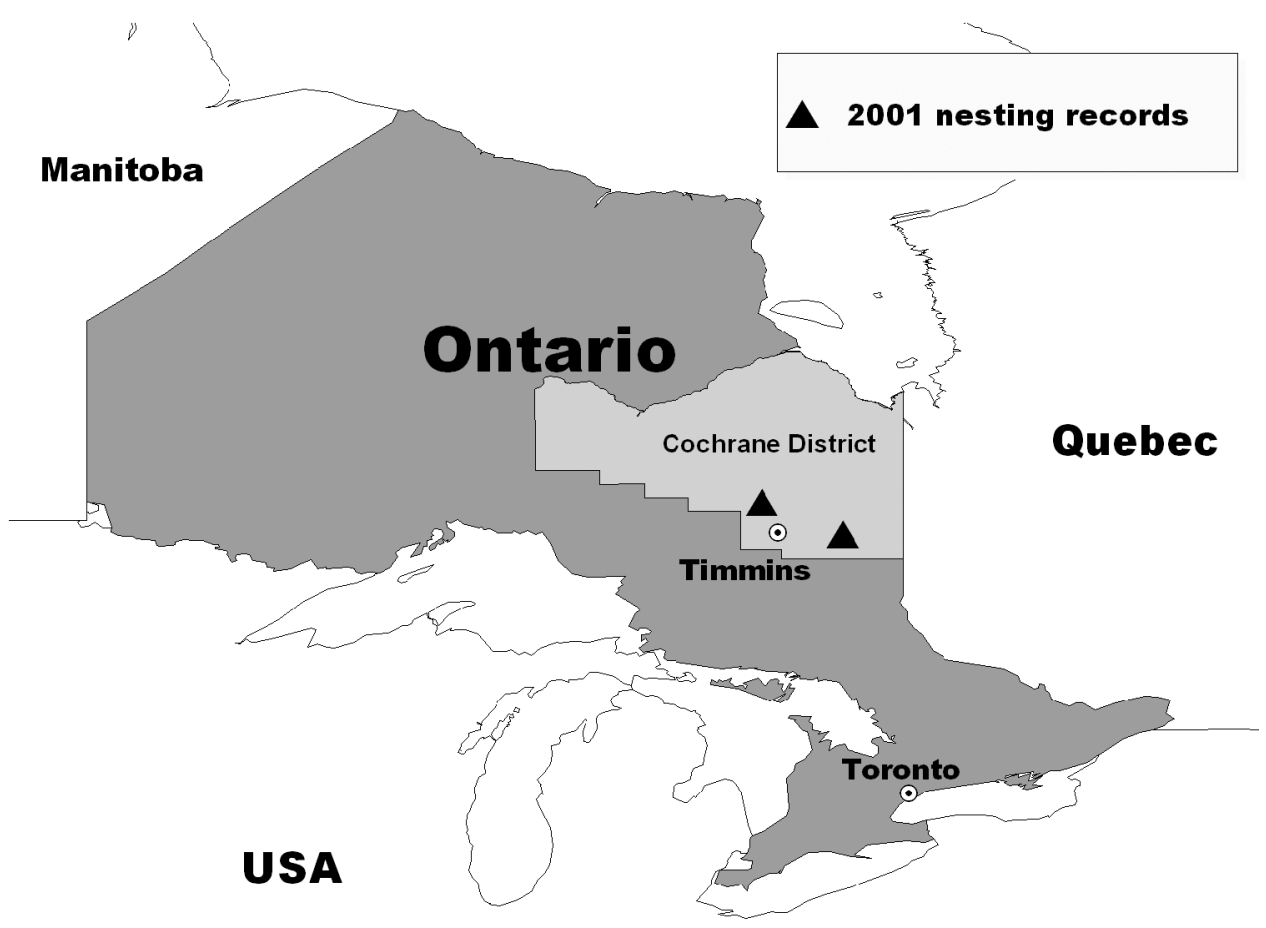

FIGURE 1. Location of the 2001 Northern Hawk Owl nesting records from Cochrane District.

wind. At least one young begged for food on 25 June in the nest vicinity, but it could not be located in the thick growth of spruce and Balsam Fir. The young were likely only ca. 14-18 days old when the high winds struck. Elsewhere in North America, the young leave the nest when 20-30 days old (Kertell 1986; Lane and Duncan 1987).

The fate of nest Number 2 was unknown. The female was in the nest cavity and presumably incubating up to 28 May. On 29 May the female was sitting in an incubating posture higher than previously, suggesting that the young might have hatched. On 10 June, both adults were near the nest displaying aggressive behavior and uttering alarm calls, but no owls visited the nest between 07:45 and 10:00 hrs on the following day, 11 June (when observed from a blind), and no young called. Hawk Owls were also observed not far from nest Number 2 on 25 and 30 June, but no alarm or begging calls were heard. Escott (2002) reported a nest failure near a busy logging road in Thunder Bay District, but traffic near this nest was moderate at the most and unlikely had anything to do with the nest's fate.

In the Shallow River Valley breeding area one fledged young was observed on 13 June, and four fledglings at the same site on 23 June. The largest of these young was completely feathered on 23 June when the other three still had some down on heads and bodies (Figure 4). One flew ca. $20 \mathrm{~m}$ when approached thus suggesting that it was at least 30 days old (see Duncan and Duncan 1998).

Some information on nesting and feeding behavior of this species was gathered while observing nest Number 1 . The female from that nest never left it during several short visits 19 to 29 May, and 3.5 hours of observation on 30 May (presumably incubating). The male was calling (advertising call, Mikkola 1983) from perches in the vicinity. On one occasion the incubating female also uttered an "ulululu" call very similar to advertising call of the male. After the young hatched, the female sometimes left the nest to hunt, or perched in the vicinity (up to ca. $100 \mathrm{~m}$ from the nest) calling for food from time to time. On 11 June, during 6 hours of observation, the female was absent from the nest for a total of 73 minutes, and on 12 June ( 5 hours of observation) for 71 minutes. On average, she was absent for $24 \pm 21.9$ minutes at a time (range 3-65 minutes, $n=6$ ). These numbers do not include short absences when the female flew off the nest to meet the male delivering food.

During the observation period food was brought to the female between 11:20 and 20:00 hrs. On eight occasions, the male flew directly to the nest, but on 12 June two food transfers occurred outside the nest. The male never lingered, leaving the nest in ca. 10 seconds after passing food to his mate, but he often perched nearby. At nest Number 2, the male was seen deliver- 


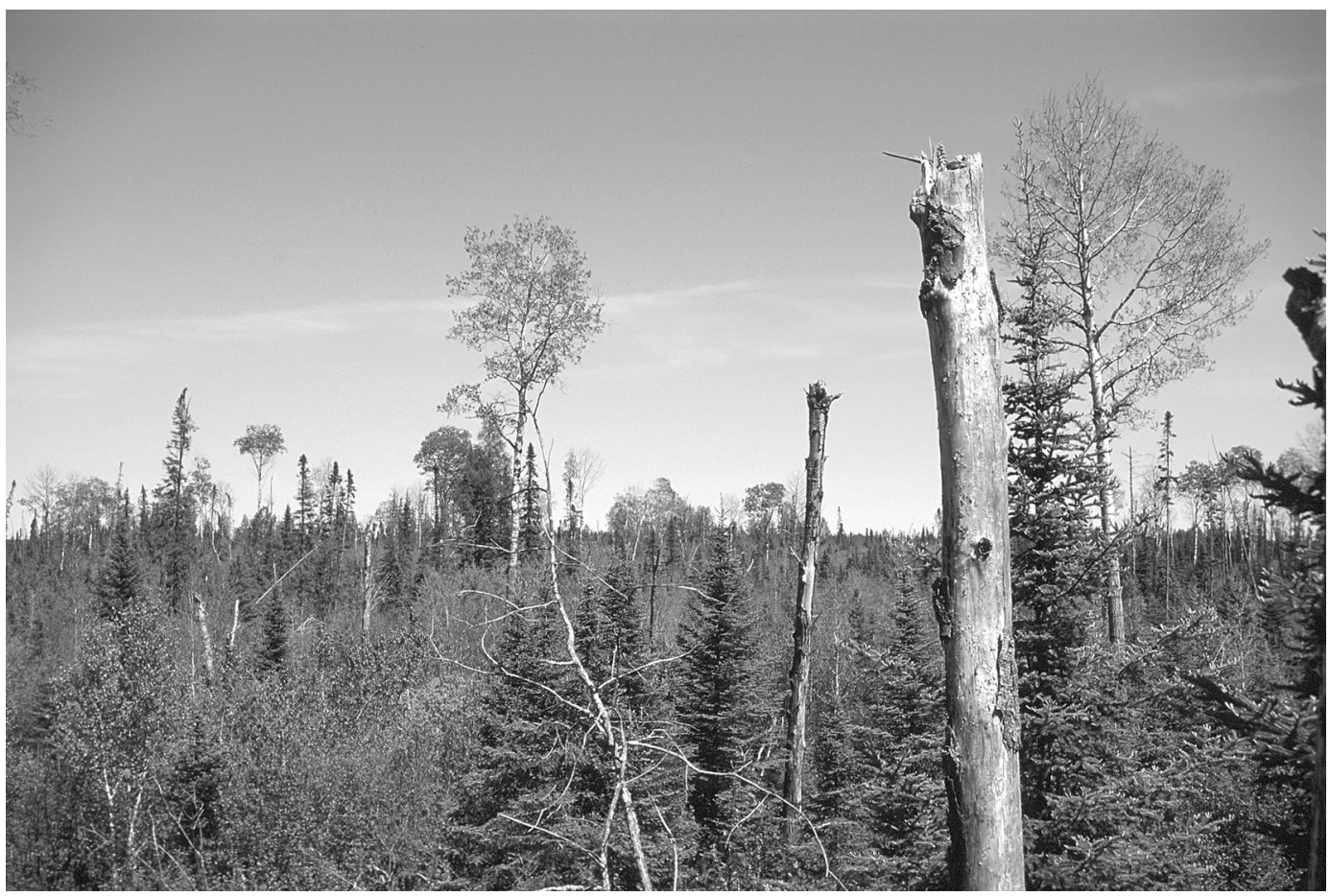

FIgURE 2. Nesting habitat and nest site of Northern Hawk Owl, Surnia ulula caparoch, in Cochrane District of Ontario. Incubating owl could be seen at the top of the snag in the foreground (nest Number 1). Photo by Michael Patrikeev in 30 May 2001.

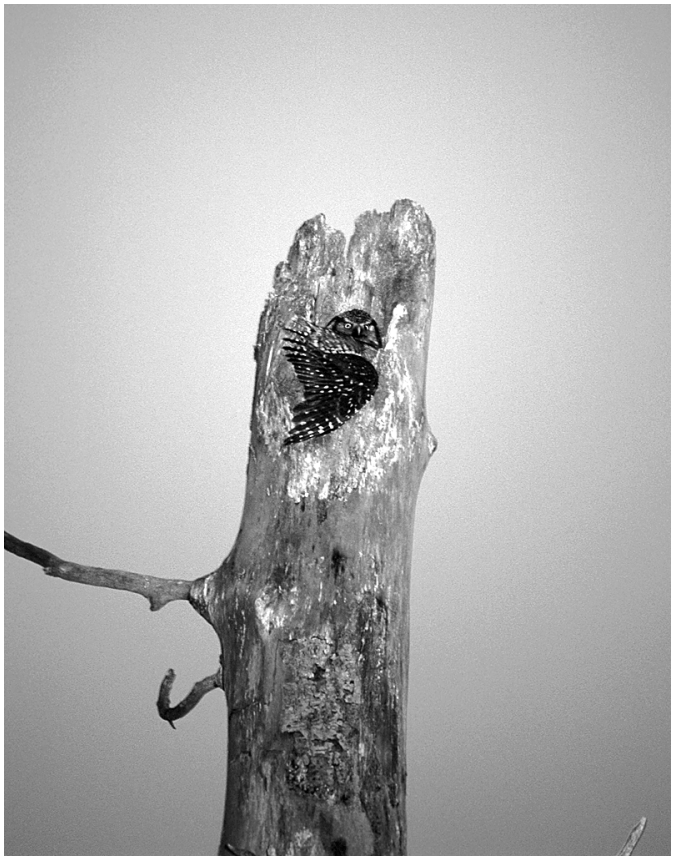

FIGURE 3. The second nest found in Crawford Township was in a cavity open on one side. Photo by Michael Patrikeev 30 May 2001.

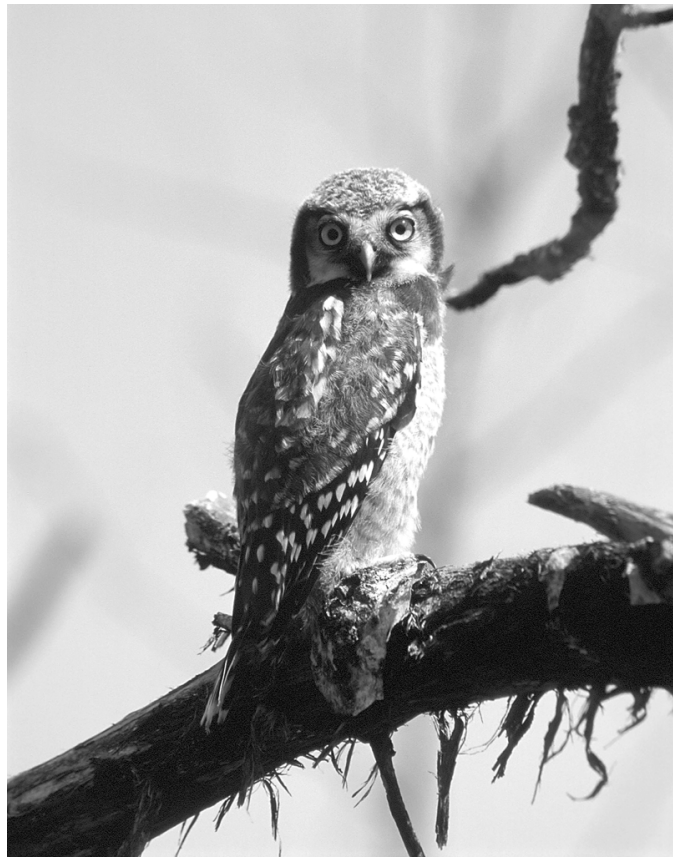

FIGURE 4. This large fledgling Northern Hawk Owl was photographed in Wilkie Township, near Iroquois Falls, on 23 June 2005. Photo by Michael Patrikeev. 
ing to the nest once, and twice the food transfer took place outside the nest. Prey delivery intervals at nest Number 1 varied from 49 minutes to 3 hours and $8 \mathrm{~min}$ utes (on average 120.4 minutes \pm 66.3 minutes, $n=8$ ). These were longer than intervals between feeding of fledglings reported by Lang et al. (1991) from northern Manitoba: $48.5 \mathrm{~min} \pm 34.9 \mathrm{SD}(n=12$, range 10 $130 \mathrm{~min}$ ). Of 10 observed prey items 7 were Meadow Voles (Microtus pennsylvanicus), 1 Northern Shorttailed Shrew (Blarina brevicauda), and the remaining two were either small mammals or small birds. The male removed heads of some voles before bringing them to the nest, whereas other prey was delivered whole. Prey beheading was also reported by Duncan and Duncan (1998). It was unclear whether the male ate the heads, as no cranial or dental material was found in pellets cast in the vicinity of the nest, although on one occasion, the female swallowed a prey item whole, head first. The female fed the young from beak to beak or held a partially skinned vole over the young's heads allowing them to tear at the carcass (Figure 5).

In southern Cochrane District in 2001, Northern Hawk Owls nested in recent cutovers possibly treated with herbicides to stress regeneration of deciduous trees. These owls are known to utilize clearcuts for nesting (Duncan and Duncan 1998), and they showed preference for chemically treated clearcuts in northwestern Ontario during their influx in the early 2000s (Escott 2002). Clearcuts with tall snags and few shrubs possibly mimic recently burned areas and other open habitats preferred by this species in its core range further north, and provide both nesting sites and open hunting habitat (Duncan and Duncan 1998). Populations of some prey species (e.g., Meadow Vole) may be more numerous in recent cutovers (Sullivan et al. 2004). Clear-cutting in northeastern Ontario will likely create more ephemeral nesting habitat for this species providing that groups of trees and snags remain after cutting.

\section{Acknowledgments}

I thank James R. Duncan (Manitoba Conservation, Winnipeg, Manitoba), Jack C. Eitniear (San Antonio, Texas), A. J. Erskine, and an anonymous reviewer for useful comments and suggestions regarding the manuscript, George Peck (Royal Ontario Museum) for providing me with unpublished Northern Hawk Owl nest records, Audrey Heagy (Bird Studies Canada, Port Rowan, Ontario) for assisting in the review of the literature and helping to obtain unpublished OBBA information, and Jay Malcolm (University of Toronto, Ontario) for information on small mammals and clearcuts.

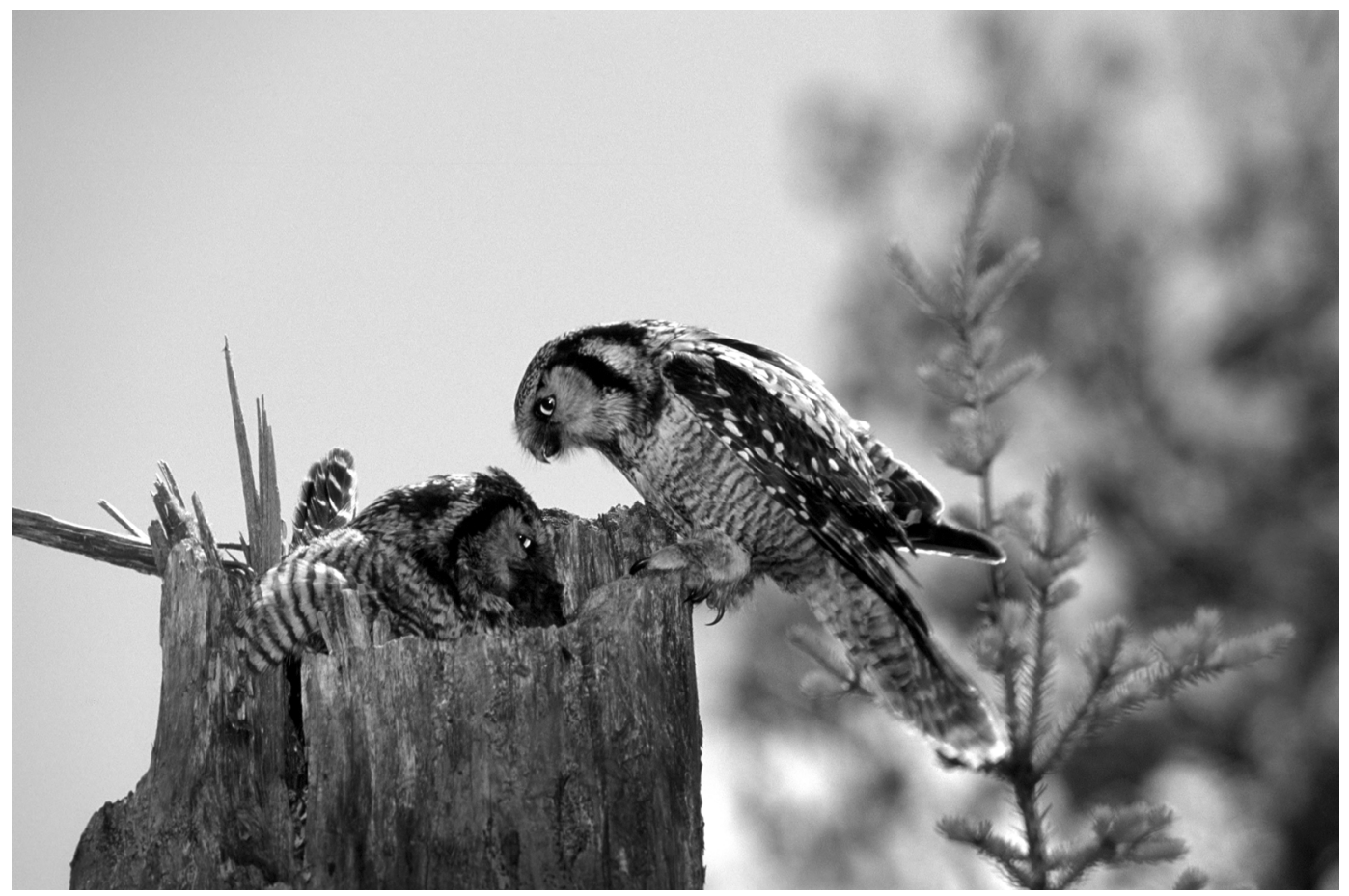

FIGURE 5. Pair of Northern Hawk Owls at nest. The male had just delivered a carcass of a Meadow Vole, and the female (on the left) is holding the vole over the youngs' heads allowing them to tear at the carcass (nest Number 1). Photo by Michael Patrikeev' 11 June 2005. 


\section{Literature Cited}

Duncan, J. R., and P. A. Duncan. 1998. Northern Hawk Owl (Surnia ulula). In The birds of North America (356). Edited by A. Poole and F. Gill. The Birds of North America, Inc., Philadelphia, Pennsylvania. 28 pages.

Escott, N. G. 2002. An influx of the Northern Hawk Owl in Thunder Bay District. Ontario Birds 20: 75-86.

Kertell, K. 1986. Reproductive biology of Northern Hawkowls in Denali National Park, Alaska. Journal of Raptor Research 20: 91-101.

Lane, P. A., and J. R. Duncan. 1987. Observations of Northern Hawk-owls nesting in Roseau County. Loon 59: 165174.

Lang, A. L., J. R. Duncan, S. Ramsay, and J. D. Rising. 1991. Great Gray Owl and Northern Hawk Owl nests at Churchill, Manitoba. Blue Jay 49: 208-214.

Mikkola, H. 1983. Owls of Europe. Buteo Books, Vermillion, South Dakota. 440 pages.
Peck, G. K., and R. D. James. 1983. Breeding birds of Ontario: Nidiology and distribution. Volume 1: Nonpasserines. Life Sciences Miscellaneous Publication, Royal Ontario Museum, Toronto, Ontario. 321 pages.

Sullivan, T. P., D. S. Sullivan, and P. M. F. Lindgren. 2004. Small mammals and stand structure in young pine, seed tree, and old-growth forest, southwest Canada. Forest Ecology and Management: 373-386

Weir, R. D. 1987. Northern Hawk-Owl. Page 542 in Atlas of the Breeding Birds of Ontario. Edited by M. D. Cadman, P. F. J. Eagles, and F. M. Helleiner. Federation of Ontario Naturalists and Long Point Bird Observatory, University of Waterloo Press, Waterloo, Ontario. 617 pages.

Received 28 November 2005

Accepted 3 May 2007 